we think our aim has been slightly rnisconceived. When we observed in the Introduction to the first volume that Cicero often uses a Greek word where with us a French term has become almost naturalised, we wished merely to point to a curious coincidence. We added that Greek expressions in the Letters often correspond rather to our slang; and that sometimes Cicero borrows an expression from the Greek where we have recourse, not to Greek nor to any vernacular argot, but to some familiar Latin phrase or tag. Some recent translators, especially Rev. G. E. Jeans, whose translation is in most respects a model of vigour and grace, have shown a flattering appreciation of our little remark by always rendering Greek into French. Indeed, we have been accused of negligence in not always finding French parallels ourselves. This, we submit, is asking us to do somfething which we never undertook, and which, with all our respect for Mr. Jeans' conspicuous tastefulness, we think would be both useless and misleading, if carried out.
When a foreign expression, be it French German or Italian, has won its way into our tongue so securely that we invariably use it in default of an exact English equivalent, then, and then only, should it be admitted into a translation of the Letters.

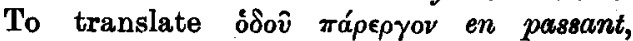

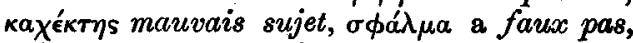

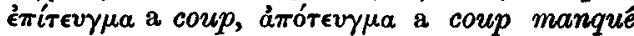

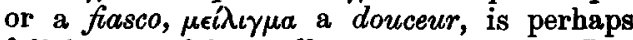
felicitous and is at all events natural. But to represent Greek by French expressions which have in no sense won their way into our language, seems to us to misrepresent the character of the Letters. Who would think of writing in an English letter infaisable, sel attique, l'apothéose d'un consulat, ami de la patrie, pitié de soi-même? Such employment of unfamiliar and colourless French expressions might even suggest to English readers a pedantry, a want of taste, or a limitation of vocabulary, from which Cicero certainly did not suffer.'

R. Y. TYrRelL.

\title{
THE ENGLISH PROSPECTUS OF THE THESAURUS LINGUAE LATINAE.
}

IT is probable that all the readers of the Classical Review have received, from one source or another, the scandalous piece of 'English as she is spoke' that has just issued ex aedibus B. G. Teubneri. The German Prospectus, or at least the greater part of it, was presumably written by the Committee in charge of the production of the Thesaurus. It is inconceivable that any of its members, the leading scholars of five German Universities, Berlin, Göttingen, Leipzig, Munich, and Vienna, had a hand in the Translation that is before us. It is sad that they were careless enough to delegate such important work to an incompetent subordinate. There is scarcely a paragraph that is good English. 'In innumerable questions the $\mu$ étpov of judgment will here be found and ultimately firm knowledge will and must take the place of subjective liking and straying phantasy.' 'Certain conjectures were indicated as such with specification as to their tradition, bannishing doubtful out of the text one preferred to make use of the tradition indicated as corrupt-all this to provide an irrefutable foundation for reliable quotations.'

A want of feeling for style in one foreign language promises badly enough for success in interpreting another. But how are we to feel any confidence at all in a Dictionary whose six-paged Prospectus contains eighteen serious misprints, not counting questions of punctuation? One of these misprints is unpardonable. 'Next follows marked as audacter the Statius quotation where animosus frigus marks the thrill of ambitious pride namely of a horse.' Audacter indeed!

The French Translation that reaches us through $H$. Welter of Paris seems to be more successful than the English in avoiding misprints. In style it is no better; a French colleague of mine maintains that it is worse. 